\title{
EXCURSION TO EAST WICKHAM AND PLUMSTEAD.
}

\author{
Saturday, September 6th, igig. \\ Report by H. A. Baker, M.Sc., F.G.S., and S. Priest, F.G.S., \\ Directors of the Excursion.
}

ABout twenty members met near Plumstead Church at 2.30 p.m. and proceeded first to Bostall Hill Road. Opposite Rochdale Road, a turn south into a road-cutting skirting the western fringe of Bostall Woods enabled the party to inspect sections through downwash, composed of debris from the higher ground of the woods. Material from the green basement loams of the Woolwich Beds was much in evidence, and in one place a preliminary digging operation had disclosed the presence of some thickness of material from the shelly clays of the Woolwich Beds. A pebbly deposit composed of material from the Blackheatl Beds had also accumulated to a thickness of several feet in places. One or two members were at first disposed to think that the section showed Lower Tertiary Beds in place, but it was pointed out that at this level (only a few feet above the Chalk) the Thanet Sand should come on, and further, that the section here seen is not at all in keeping with the well-known sequence of the beds in this district.

Near Waterdale Road a small pit showed Chalk which has been taken to represent a high-level in the zone of Micraster coranguinum. The chalk is hard and fractured and the few fossils which occur are mostly broken. The suggestion that the Chalk here has been affected by slight faulting movement was regarded favourably. At the small stream flowing in a Chalk bed down the East Wickham Valley the suggestion was made that the valley may be due to some extent to faulting, as well as to erosion by the stream. The sides of the valley are crenulated by small subsidiary "slades," where springs burst out, and certain anomalies in the levels at which the component members of the Woolwich Beds crop out suggest slight faulting. From King's Highway, Messrs. Tuff and Hoar's pit was entered. Here a very fine section showed :-

Blackheath Pebble Beds .. $\quad . . \quad \ldots \quad$ up to gfeet.

Woolwich Basement green loams, with very slight pebble courses $\quad . . \quad \ldots \quad$.. $\quad 7$ feet.

$\begin{array}{llllll}\text { Thanet Sands } & \ldots & \ldots & \ldots & \ldots & 66 f e e t .\end{array}$

Bullhead Bed, with (?) Allophane .. $\quad$.. 6ins. to Ifoot.

Chalk, high in $M$. coranguinum-zone, $\quad$. seen for 8 feet.

The (?) Allophane from the Bullhead Bed may be the allicd 
mineral halloysite. Mr. Baker describes it as a whitish, waxylooking, brittle substance, with a hardness of 3 . It falls to powder before the blowpipe, is soluble in dilute hydrochloric acid and in strong acid forms a jelly-like substance.

Continuing along King's Highway to the Alma Tavern, the members entered the abandoned brickfield adjoining Woolwich Cemetery. The section here, although once very fine, is now much overgrown. It was described and figured in $x 906$ by Mr. A. L. Leach. It may be summarised as follows :-

Blackheath Pebble Beds .. .. .. up to 5 feet.

Thanet Sand $\quad \ldots \quad \ldots \quad \ldots \quad \ldots$ up 56 feet.

(Thin, evenly bedded sands with"

thin clay partings. Equivalent

of "leat-bed " of Lewisham .. I4feet.

Woolwich
Beds. $\left\{\begin{array}{l}\text { Stiff dark clay with Cyrena and } \\ \text { Ostrea shell-beds .. .. .. }\end{array}\right.$

Compact, fine, light grey sand .. r rofeet.

Stiff green loam $\quad \ldots \quad$.. $\quad \ldots \quad$ r3feet.

In the section only the upper part of the Thanet Sand is seen, but there is a shaft (now sealed) leading to extensive underground workings in the Chalk.

In the Woolwich Series, the Basement green loams form the most persistent member throughout the district.

Pleistocene (Middle Terrace) brick-earths here have yielded mammalian remains.

The continuation of the section showed very clearly the pebble-splashing at the junction of the Woolwich Beds and Thanet Sand.

The members next walked as far as the White Horse Inn, on the hilltop at East Wickham. The section here was formerly in much better condition than it is at present. A thickness of some I4 feet of Blackheath Pebble Beds is now to be seen, and the section has yielded many quartzite-pebbles to the Directors and others. Mr. A. L. Leach stated that the junction with the Upper Woolwich loams could formerly be seen. Wet ground will, even now, lead the way to a small section in these striped loams, but having nothing more definite than a pebbly drift at the top.

Attention was directed to the marked splintering of the pebbles. Mr. Priest states that this splintering occurs more particularly along several short but easily recognisable lines. In the discussion a difference of opinion arose, some thinking that the splintering may have been due to temperature changes since the opening of the section, whilst others preferred to associate it with pressure and movement in the beds. Generally, the splintered fragments are still held together in the bed.

Mr. E. E. S. Brown writes:- "With reference to the sec- 
tions in the Blackheath Pebble Beds, near Fanny-on-the-Hill, showing numerous splintered pebbles in situ, I agree with the suggestion that the phenomenon is probably due to pressure. In view of the frequent slipping of Eocene beds on the hill-sides (often by small step-faults), such movement may perhaps be a contributory cause; and possibly the actual fractures may occur during slight movements under great pressure. The objection that similar splintering does not occur in other Eocene pebble-beds may be met by the fact that here the pebbles are large and in remarkably close contact with each other. I cannot agree that the pebble splintering is due to changes of temperature and weathering, for numerous disused sections of pebblebeds in North Kent have been exposed for an equally long period, and yet they do not show this phenomenon."

During the descent to Wickham Lane, Mr. A. L. Leach, on the invitation of the Directors, referred to the extensive underground workings for chalk in this neighbourhood. Beneath the East Wickham valley, chalk has been extensively worked, solely for use in brickmaking. When the old workings at the "Caves" at Bostall Woods proved inadequate, a shaft was sunk at the "Cemetery" Brickfield and an extensive system of long and high galleries worked from this centre, which was the sole means of ingress and exit. The workings were therefore of a type precisely similar to the well-known galleries at Chislehurst. The workings are now abandoned and the shaft sealed, but the site of the latter can still be seen in the "Cemetery" Brickfield.

The party next proceeded by car to the Borough Museum at the Plumstead Library and a short time was spent in examining the contents of the geological collection. Mammalian remains from the Pleistocene brick-earth of East Wickham were noted, also a good collection of Chalk and Eocene fossils, which included many local specimens.

By the kindness of the librarian-in-charge, Mr. E. Luke, the members were then provided with chairs, while Mr. Baker made some remarks on certain special features exhibited by the Chalk and Tertiary Beds of the district, and afterwards opened a discussion on the interesting quartzite-pebbles occurring in the Blackheath Pebble Beds.

During his earlier remarks Mr. Baker showed a pair of maps, the first representing, by means of isopachytes (lines of equal thickness of strata), the variation in thickness of the Chalk formation in the London area, beneath the Tertiary cover, and the second the variation in thickness of the load of strata resting upon the Chalk in the same area.

It was pointed out that the Chalk of the London area apparently shows a variation in thickness from above 750 feet to 450 feet, or even less, and the interesting point was men- 
tioned that whereas in the neighbourhood of the Thames the Chalk appears to be over 700 feet thick with its upper beds in the $M$. coranguinum-zone, yet, farther south, at Orpington, where the Chalk appears to be under 500 feet thick, the uppermost zone is that of Uintacrinus, while at Farnborough the Marsupites-zone occurs. Mr. Baker, in stating that this southerly thinning of the Chalk formation was no new fact, as it had been detected and referred to some years ago by G. W. Young and Jukes-Browne,expressed the opinion that this feature is indicative of a significant movement of uplift to the south of the London area during the formation of the Upper Chalk.

In referring to the second map, showing the thickness of the load of strata (chiefly Eocene) upon the Chalk, the point was made that this clearly brings out the striking fact that where the Chalk formation is thickest, the Eocenes are thinnest, and vice versa. There had been what might be termed compensatory deposition, the Eocenes having been laid down in such a way as to tend to level-up the inequalities in the Chalk surface.

The speaker then referred to the results afforded by mechanical analyses (by elutriation) of a large number of samples of the Lower London Tertiary Beds, many of which had been collected from the sections visited that day. The details of the process of elutriation were briefly described, and a graphical method of representing the results obtained was explained. A method of expressing the average coarseness of a sediment by means of a representative number was also referred to. A large number of the elutriation-curves yielded by samples of Thanet, Woolwich and Blackheath sands were exhibited. It was shown that, with regard to the Thanet Sand, there is a conformity to a distinctive type of curve, with a definite range from coarser to finer sediment from top to base. The curves for Woolwich and Blackheath Beds show greater variety and emphasize the varying character of these beds as observed in the field. The speaker hoped that, at a later stage, he would be in a position to interpret more fully the meaning of the elutriation-curves of sediments, when he had accumulated more data.

In opening the discussion on the quartzite-pebbles which occur in the Blackheath Pebble Beds, Mr. Baker exhibited a collection of these pebbles. He referred to the remarks of Dr. G. J. Hinde* concerning these quartzite-pebbles, wherein the difficulty of accounting for their presence in the Tertiary pebblebeds was alluded to and Prestwich's suggestion repeated that they may have come from the quartzites of the Palæozoic rocks of the Ardennes, and stated that, so far as published information went, the question still remained at that stage. The speaker mentioned that, of late, much discussion had centred round the question as to whether these pebbles are, or are not, sarsen-

- Proc, deol, Assoc, vol. xi., 18ga, p. 467. 
stones, but he proposed to discuss them simply as pebbles from the Blackheath Beds. The substance of the remarks made is as follows:- These pebbles are rare, but not so rare as has been supposed. They are apparently always to be found where Blackheath Pebble Beds occur, and are found in sea-beaches in the neighbourhood of the outcrop of L-ower Tertiary beds, e.g., Shoreham near Brighton, Reculver and Dovercourt. It is notable that they do not occur at Pegwell Bay, where the Tertiary cliff-section is in Thanet Beds only. The pebbles often possess a characteristic flattened ovoid shape, suggesting derivation from hardened tabular masses, but this is not an invariable feature. They vary in size, but are usually not small. They often show a mottled external appearance, due to incomplete silicification, and interesting cxamples exhibiting a wavy, banded structure are known.

When slices are examined under the miscroscope it can be seen that the pebbles are not metamorphic rocks at all, in the strict sense. They are not the result of either contact or regional metamorphism, although they afford examples of atmospheric metamorphism. A metasomatic change has taken place within the rock, fresh silica having been introduced as a ccmenting medium. They are entitled to the name "quartzite" by virtue of the fact that they are rocks composed chicfly of quariz grains, with the addition of a quartz cement. They are, in fact, sandstones or grits cemented by secondary silica. The texture is variable and patchy -in parts of one and the same slide the rock might often be described as (a) Sandstone, (b) Grit, (c) Quartzite. There is no secondary outgrowth from the grains and no sign of optical continuity between original grains and secondary silica. The secondary silica is often amorphous, possibly colloidal, and dirty with disseminated iron-oxide. Approach to a quartz-mosaic structure is seen only rarely and locally, and when it occurs the grains are very small and the feature appears to be developed only in the secondary silica.

Examination of the sections reveals the presence of other minerals, such as tourmaline, kyanite, staurolite, rutile, zircon and iron-oxides.

When the quartzites are crushed and the heavy minerals are isolated by the use of a heavy liquid, such as Thoulet's (Sonstadt's) solution, with a special gravity of 2.80 , the very characteristic and unmistakable assemblage of the Lower London Tertiary beds themselves is obtained.

Following on these remarks, the spcaker drew special attention to a quartzite-pebble, which he had obtained in situ from the Blackheath Pebble Beds at Plumstead. In this interesting specimen numerous well-rounded pebbles of Chalk-fint were seen to be included. Summing-up his remarks, he expressed the opinion that the evidence pointed to the derivation of these 
pebbles from the Lower London Tertiary beds themselves, probably from the Blackheath Beds.* He considered that they might be regarded as evidence of contemporaneous erosion during the deposition of the Blackheath Beds.

During the discussion Dr. Sherlock expressed his agreement with the speaker's remarks and stated that he would have called all the specimens exhibited "sarsens." Mr. A. L. Leach expressed difficulty in seeing how these pebbles could have come from the Blackheath Beds themselves and considered that more evidence for silicification of the beds in place was desirable. He objected to the speaker's use of the term "sarsen" and enquired whether the term should not be restricted to apply to the quartzites associated with the Bagshot Beds only. Mr. L. D. Stamp mentioned that in the Sparnacian of Belgium, which he had recently had the opportunity of examining, precisely similar rolled quartzite-pebbles occur.

In addition to the quartzite-pebbles, the exhibits on the table included, for comparison, sarsens and puddingstone collected on the excursion of July 26 th to Bradenham and Walter's Ash, and Bunter quartzites from Bewdley and Stourbridge.

Mr. A. L. Leach, in a vote of thanks to the Directors, stated that the members had heard an outline of two new methods of investigation applied to a set of deposits of which it had been believed that our knowledge was comparatively complete, and that these methods promised to have far-reaching results.

Before leaving the Museum the Directors, on behalf of the members, expressed appreciation of Mr. Luke's courtesy.

The members then proceeded by car to Woolwich for tea at Messrs. Fairbrother's, and returned to town from Woolwich Arsenal Station by the 6.33 p.m. train.

Mr. F. J. Epps acted as Excursion Secretary.

\section{IREFERENCES.}

Geological Survey Map, New Series, I-inch, Sheet 4, London District (Drift).

Ordnance Maps, 6-inch, Kent, Sheets II. S.E. and S.W.

.1888. J. G. GoodchILD - " Excursion to Plumstead and Bostall." Proc. Geol. Assoc., vol. X., pp. 39-58.

1906. A. L. LeAch I. B. C.'PolkinghorNe.-." Excursion to East Wickham and Bostall Heath." Proc. Geol. Assoc., vol. xix., pp. $34 x-347$.

1907. A. L. LEach.-"Excursion to East Wickham." Proc. Geol. Assoc., vol. xx., pp. $77-78$.

1909. Woolwich Surveys. South Eastern Union Sci. Soc., pp. 3-3o.

I9I9. S. PRIEST.- "Excursion to East Wickham and Bostall Heath." Proc. Geol. Assoc., vol. xxx., part 2, pp. $8 \mathbf{z}-86$.

\footnotetext{
- Since this was written I have reconsidered the evidence, in the light of further information, and am now of the opinion that the quartzite-pebbles were derived from the Woolwich Beds. H.A.B.
} 